\title{
Effects of Irrigation Deficit and Application of Some Growth Regulators on Defense Mechanisms of Canola
}

\author{
Seyed Ahmad KALANTAR AHMADI ${ }^{1 *}$, Ali EBADI², Jahanfar DANESHIAN ${ }^{3}$, \\ Soodabeh JAHANBAKHSH ${ }^{2}$, Seyed Ataollah SIADAT ${ }^{4}$, \\ Hourieh TAVAKOLI ${ }^{2}$ \\ ${ }^{1}$ Department of Agronomy and Plant Breeding, Faculty of Agriculture, University of Mohaghegh Ardabili and \\ Safiabad Agricultural Research Center, Iran; kalantar@uma.ac.ir \\ ${ }^{2}$ Department of Agronomy and Plant Breeding, Faculty of Agriculture, \\ UniversityofMohagheghArdabili,Iran; ebadi@uma.ac.ir;jahanbakhsh@uma.ac.ir; hurinata@gmail.com \\ ${ }_{3}^{3}$ Seed andPlantImprovement Institute, Karaj,Iran;j_daneshian@yahoo.com \\ ${ }^{4}$ Department of Agronomy and Plant Breeding, University of Ramin Agricultureand Natural Resources, Khuzestan, Ahwaz, Iran; seyedatasiadat@yahoo.con
}

\begin{abstract}
A split-plot experiment arranged in a randomized complete blocks design with three replications was carried out in Safiabad Agricultural Research Center of Dezful in order to investigate the effects of foliar applications of ascorbic acid (AsA), salicylic acid (SA) and methanol (Me), under deficit irrigation conditions, in canola; there were 3 levels of irrigation as the main factor (irrigation after $70 \mathrm{~mm}$ evaporation from the pan as control, cessation of irrigation at the flowering stage and cessation of irrigation at the appearance of siliques) and 10 levels of foliar applications as sub-factor (100, 200 and 300 mg.t ${ }^{1}$ AsA; 100, 200 and $300 \mu \mathrm{M} \mathrm{SA} ; 10,20$ and 30\% (w/v) methanol; and foliar application of distilled water as control). Foliar applications were made during both budding and initiation of flowering stages. Results indicated that antioxidant enzymes showed different responses to deficit irrigation and foliar application treatments. Maximum catalase (CAT) and polyphenol oxidase (PPO) activities were observed under cessation of irrigation at flowering stage and foliar application of $300 \mu \mathrm{M} \mathrm{SA}$, while ascorbate peroxidase (APX) reached its maximum activity under the same irrigation conditions and foliar application of $300 \mathrm{mg} . \mathrm{I}^{-1} \mathrm{AsA}$. SA had more influence to increase in CAT and PPO activity under cessation of irrigation at flowering stage. The relative water content (RWC) was also decreased due to the drought stress caused by the cessation of irrigation. Foliar application of SA $(100 \mu \mathrm{M})$ and $\mathrm{Me}(10 \% \mathrm{w} / \mathrm{v})$ had more influence to maintain RWC compared to ascorbic acid under irrigation cessation at flowering stage.
\end{abstract}

Keywords: adaptation, ascorbic acid, drought, enzymes, methanol, salicylic acid, stress

\section{Introduction}

Immobility of plants has led them to be classified based on their strategies to cope with various abiotic stresses such as salinity, drought, cold and heat and their ultimate impact on plants growth and productivity (Gill et al., 2003). Adaptation to such stresses is associated with metabolic adjustments that lead to the production of different enzymes (Strain and Fletcher, 2003). Inducing drought tolerance in plants through the use of ascorbic acid could have a significant application in agriculture (Hamada, 2000). Ascorbic acid (AsA) is one of the important components of the antioxidant defense system and acts as a reducing agent in the removal of $\mathrm{H}_{2} \mathrm{O}_{2}$ (Noctor and Foyer, 1998). Some enzymatic and non-enzymatic antioxidants are produced in response to abiotic stresses in order to protect plants against the damages caused by reactive oxygen species (ROS) (Ashraf, 2009). The most important antioxidant enzymes are superoxide dismutase (SOD), catalase (CAT), peroxidase (PO) and ascorbate peroxidase (APX) while AsA and tocopherols are major non-enzymatic antioxidants produced by plants under stress conditions (Mittler, 2002). Some studies have also noted the external application of AsA and its positive impact on alleviating the damaging effects of drought (Amin et al., 2009; Khalil et al., 2010; Singh et al., 2001). External application of AsA also helps to preserve chlorophyll pigments and reduce the impact of drought stress (Malik and Ashraf, 2012). 
Salicylic acid (SA) acts as an internal signaling molecule that induces tolerance to abiotic stresses in plants. Under drought stress conditions, SA induces antioxidant enzyme activities at an increased rate compared to when it is not applied. External application of SA helps to alleviate the devastating effects of drought stress; therefore SA plays an important role in stress tolerance through reducing the loss of water and also induces the antioxidant system (Saruhan et al., 2012). CAT, PO and SOD activities increased with the application of SA under drought stress conditions (Idrees et al., 2011). Ullah et al. (2012) stated that drought stress (for 10 days during the flowering period) decreased relative water content (RWC), chlorophyll $a$, chlorophyll $b$, carotenoids and soluble proteins content, while the application of SA alleviated the harmful effects of drought stress in canola cultivars. Idrees et al. (2011) also reported that total chlorophyll and carotenoids contents were decreased under drought stress conditions, while the application of SA under the same conditions increased both.

One of the ways to increase $\mathrm{CO}_{2}$ concentration in plants is the use of compounds such as methanol, ethanol, propanol and butanol (Ramberg et al., 2002) as their major role is to reduce the impact of induced stresses in crops during their photorespiration process (Downie et al., 2004). Foliar applications of methanol enhance the growth and yield of $\mathrm{C}_{3}$ plants. Methanol is considered as a source of carbon for plants which increases the $\mathrm{CO}_{2}$ fixation in crops (Nonomura and Benson, 1992). Understanding the impact of methanol on plants is still a controversial subject since different studies conducted about its impact on photosynthetic activity and biomass production in plants have led to different results (Zheng et al., 2008). Some studies suggested that both biomass production and photosynthetic activity in algae are increased at low concentrations of methanol (Theodoridou et al., 2002). Changes in photosynthetic metabolism due to a change in environmental conditions or agricultural practices lead to a change in plant's growth and productivity (Pallardy, 2010), while the foliar applications of methanol, as an appropriate method, increased $\mathrm{CO}_{2}$ assimilation in plants (Ganjeali, 2012).

Current study was aimed to examine whether the adverse effects of drought stress on canola could be mitigated by application of ascorbic acid, salicylic acid and methanol, in different doses. Furthermore, the role of ascorbic acid, salicylic acid and methanol in antioxidant enzymes activity was also investigated. The goal of this experiment therefore was to evaluate the effects of drought stress and foliar applications of certain growth regulators on canola plants and their respective responses.

\section{Materials and methods}

This field experiment was conducted at Safiabad Agricultural Research Center in Khouzestan province of Iran ( $82.9 \mathrm{~m}$ as.l. $44^{\circ}$ $26^{\prime} \mathrm{E}, 32^{\circ} 16^{\prime} \mathrm{N}$ ) in 2013 . The design was a split plot based on a completely randomized blocks design with three replications. Main plots consisted of 3 levels of irrigation (irrigation after $70 \mathrm{~mm}$ evaporation from the pan as control, cessation of irrigation at the flowering stage and cessation of irrigation at the appearance of siliques) and sub plots included 10 levels of foliar application of plant growth regulators (100, 200 and $300 \mathrm{mgg}^{-1}$ AsA; 100, 200 and $300 \mu \mathrm{M}$ SA; 10, 20 and 30\% (w/v) methanol; and foliar application of distilled water as control). Foliar applications were made during both budding and initiation of flowering stages. The studied cultivar was Hyola401. The characteristics of soil and treatments are shown in Table 1 and 2, respectively. P and $\mathrm{K}$ were applied to supply $200 \mathrm{~kg} / \mathrm{ha}$ and $150 \mathrm{~kg} / \mathrm{ha}$ using potassium sulfate and triple super phosphate, respectively. $\mathrm{N}$ was applied at 180 $\mathrm{kg} / \mathrm{ha}(391 \mathrm{~kg} / \mathrm{ha}$ urea) with a third of it applied at the time of sowing, a third at the beginning of stem elongation and the rest during the flowering period. Plots were hand weeded during the

Table 1. Characteristics of physical and chemical properties of the soil used in the experiment

\begin{tabular}{lccccc}
\hline $\begin{array}{l}\text { Soil } \\
\text { texture }\end{array}$ & OC $(\%)$ & $\begin{array}{c}\mathrm{P} \\
(\mathrm{mg} / \mathrm{kg})\end{array}$ & $\begin{array}{c}\mathrm{K} \\
(\mathrm{mg} / \mathrm{kg})\end{array}$ & $\mathrm{pH}$ & $\begin{array}{c}\mathrm{EC} \\
(\mathrm{ds} / \mathrm{m})\end{array}$ \\
\hline $\begin{array}{l}\text { Clay- } \\
\text { Loam }\end{array}$ & 0.62 & 8.5 & 178 & 7.64 & 0.57 \\
\hline
\end{tabular}

Table 2. The characteristics of treatments in the experiment

\begin{tabular}{|c|c|c|}
\hline $\begin{array}{l}S_{1}: \text { Optimum } \\
\text { irrigation }\end{array}$ & $\begin{array}{c}S_{2} \text { : Cessation of } \\
\text { irrigation at flowering } \\
\text { stage }\end{array}$ & $\begin{array}{c}S_{3} \text { : Cessation of } \\
\text { irrigation at silique } \\
\text { stage }\end{array}$ \\
\hline $\begin{array}{l}\text { AsA } 100 \mathrm{mg} \cdot \mathrm{l}^{-1} \\
\text { ascorbic acid }\end{array}$ & $\begin{array}{l}\text { AsA }_{2}: 200 \text { mg.l } .^{-1} \\
\text { ascorbic acid }\end{array}$ & $\begin{array}{l}\text { AsA }_{3}: 300 \mathrm{mg} \cdot \mathrm{l}^{-1} \\
\text { ascorbic acid }\end{array}$ \\
\hline $\begin{array}{l}\text { Saı: } 100 \mu \mathrm{M} \text { salicylic } \\
\text { acid }\end{array}$ & $\begin{array}{c}\text { Saz: } 200 \mu \mathrm{M} \text { salicylic } \\
\text { acid }\end{array}$ & 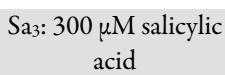 \\
\hline $\mathrm{Me}_{1}: 10 \%$ methanol & $\mathrm{Me}_{2}: 20 \%$ methanol & $\mathrm{Me}_{3}: 30 \%$ methanol \\
\hline $\begin{array}{l}\text { Control: Foliar with } \\
\text { distilled water }\end{array}$ & & \\
\hline
\end{tabular}

season. The distance between ridges was $75 \mathrm{~cm}$, sowing 2 rows on each ridge. Plots were planted and after seedling establishment, the plants were tinned to achieve a density of 80 plants $/ \mathrm{m}^{2}$. Each sub plot consisted of 4 ridges.

\section{Totalprotein assay}

In order to extract protein, $0.2 \mathrm{~g}$ of fresh plant tissue was pulverized in a mortar using liquid nitrogen and then $1 \mathrm{ml}$ of buffer Tris- $\mathrm{HCl}(0.05 \mathrm{M}, \mathrm{pH}=7.5)$ was added. The obtained mixture was centrifuged for $20 \mathrm{~min}$ at $13,000 \mathrm{rpm}$ at $4^{\circ} \mathrm{C}$ and the supernatant was used for enzyme activity measurements (Sudhakar et al., 2001).

\section{Catalase (CAT) assay}

Catalase activity was assayed according to Kar and Mishra (1976). The $60 \mu \mathrm{l}$ protein extract was added to Tris buffer (50 $\mathrm{mM}, \mathrm{pH}=7$ ) and $0.3 \mathrm{ml} \mathrm{H}_{2} \mathrm{O}_{2} 5 \mathrm{mM}$ in the ice bath, then the absorbance curve was considered at a wavelength of $240 \mathrm{~nm}$ for one minute every twenty seconds, then examined their average; CAT activity was expressed as absorbance in $\mathrm{mg}$ protein per minute. Enzyme activity was obtained for $\Delta \mathrm{OD}$-mg-protein min $^{-1}$ in fresh tissue.

\section{Polyphenoloxidase (PPO) assay}

Polyphenol oxidase enzyme activity was measured by Kar and Mishra (1976) method. $100 \mu \mathrm{l}$ protein extract was solved in $1.5 \mathrm{ml}$ of $0.2 \mathrm{M}$ Tris and $0.3 \mathrm{ml}$ of $0.02 \mathrm{M}$ Pirogalol and the resulting complex was placed in the bain marie bath at $25{ }^{\circ} \mathrm{C}$ for five minimums and then the absorbance rate at $420 \mathrm{~nm}$ was recorded.

\section{Peroxidase (PO) assay}

Peroxidase activity was measured as described by Kar and Mishra (1976): $50 \mu \mathrm{l}$ of protein extract was added to $2.5 \mathrm{ml}$ 
126

Table 3. ANOVA results of the studied characteristics

\begin{tabular}{|c|c|c|c|c|c|c|c|}
\hline SOV & Df & Catalase & Polyphenol oxidase & Peroxidase & $\begin{array}{l}\text { Ascorbate } \\
\text { peroxidase }\end{array}$ & Soluble sugars & RWC \\
\hline Replication & 2 & 776.79ns & $954.62 \mathrm{~ns}$ & $1827.81 \mathrm{~ns}$ & $66.76 \mathrm{~ns}$ & $0.00015 \mathrm{~ns}$ & $1.026 \mathrm{~ns}$ \\
\hline Stress & 2 & $18817.08^{* *}$ & $41117.11^{* *}$ & $50619.76^{* *}$ & $5427.51^{* *}$ & $0.057^{* *}$ & $2.03 \mathrm{~ns}$ \\
\hline Error & 4 & 343.67 & 420.34 & 215.44 & 154.96 & 0.0003 & 1.026 \\
\hline Regulators & 9 & $58242.83^{* *}$ & $37960.16^{* *}$ & $97.491 .58^{* *}$ & $2869.02^{* *}$ & $0.081^{* *}$ & $123.98^{* *}$ \\
\hline Stress $\times$ Regulators & 18 & $9561.5^{* *}$ & $5958.03^{* *}$ & $60193.9^{* *}$ & $502.44^{* *}$ & $0.028^{* *}$ & $46.48^{* *}$ \\
\hline Error & 54 & 449.88 & 447.65 & 1178.92 & 136.97 & 0.0005 & 1.026 \\
\hline $\mathrm{CV}$ & & 11.36 & 13.16 & 10.95 & 7.66 & 8.66 & 1.08 \\
\hline
\end{tabular}

extraction buffer containing $100 \mu \mathrm{M}$ Tris Buffer, $100 \mathrm{mM}, 5 \mathrm{mM}$ hydrogen peroxide and $10 \mathrm{mM}$ Pirogalol in the ice bath; absorbance changes were read at a wavelength of $425 \mathrm{~nm}$ graph. Enzyme activity was obtained for $\triangle \mathrm{OD}$-mg-protein $\mathrm{min}^{-1}$.

Ascorbateperoxidase (APX) assay

Ascorbate peroxidase activity was measured by the method described by Webb and Allen (1995). $2 \mathrm{ml}$ buffer phosphate ( $0.05 \mathrm{M}, \mathrm{pH}=7$ ) were mixed with $40 \mu \mathrm{L} \mathrm{H}_{2} \mathrm{O}_{2} 5 \mathrm{mM}$, then 0.2 $\mathrm{ml}$ protein extract was added. After, $20 \mu \mathrm{l}$ ascorbate $(50 \mu \mathrm{M})$ was added and the absorbance rate was noted at $290 \mathrm{~nm}$.

\section{Solublesugars assay}

To measure the amount of carbohydrates, an alcoholic extract was first prepared from the leaves. In this regard, $0.5 \mathrm{~g}$ of leaf tissue was first completely homogenized using a porcelain mortar. Then $5 \mathrm{ml}$ of $95 \%$ ethanol were added to it and the solution was transferred into a capped test tube and vortexed for 30 seconds. The supernatant was separated and transferred to another tube and then $70 \%$ ethanol was added to the remaining solid part twice, $5 \mathrm{ml}$ each time, and washed out completely. The supernatant was ultimately transferred to a test tube and $15 \mathrm{ml}$ of the extract was obtained. The resulted extract was then centrifuged at 3,500 rpm for $15 \mathrm{~min}$. The supernatant solution was then used to measure the soluble sugars according to the method proposed by Ndoumou et al. (1996). The absorbance was then measured using a spectrophotometer at a wavelength of $625 \mathrm{~nm}$.

\section{Relative water content $(R W C)$ assay}

Relative water content was measured by the method of Weatherly (1995): RWC $=($ FW-DW $) /(T W-D W) \times 100$, where FW is the fresh weight, DW the dry weight and TW is the turgid weight of tissue after being soaked in water for 4 hour at room temperature.

\section{Statistical analysis}

Statistical analysis was performed using SAS software. Mean comparisons were also performed using Duncan's multiple range test at $\mathrm{P} \leq 0.05$.

\section{Results and discussions}

\section{Catalase (CAT)}

ANOVA results showed that irrigation deficit, application of growth regulators and their interaction had a significant effect on CAT activity (Table 3). Maximum CAT activity (372.93 $\triangle$ OD-mg-protein $\mathrm{min}^{-1}$ ) was observed under cessation of irrigation at the flowering stage conditions and foliar application of $300 \mu \mathrm{M} \mathrm{SA}$, compared to its minimum activity $(33.63 \Delta \mathrm{OD}$ - mg-protein $\min ^{-1}$ ) under control treatment conditions and foliar application of $300 \mathrm{mg} \cdot \mathrm{I}^{-1}$ AsA (Fig. 1a). CAT activity at all SA concentrations was higher than that of other foliar application treatments under all irrigation levels (Fig. 1a). The use of 10\% $(\mathrm{w} / \mathrm{v})$ methanol increased CAT activity under severe deficit irrigation conditions (cessation of irrigation at the flowering stage) while the same thing was not observed using foliar applications of $20 \%$ and $30 \%(\mathrm{w} / \mathrm{v})$ methanol under the same irrigation conditions. Canola plants also showed different responses to different concentrations of AsA and various irrigation deficit conditions in this experiment. Results showed that increasing AsA concentrations under cessation of irrigation at the flowering stage conditions increased CAT activity. However, increasing AsA concentrations decreased CAT activity under cessation of irrigation at the appearance of siliques conditions (Fig. 1a). The antioxidant system, by the way, may not possess the required capacity to mitigate the harmful effects of oxidative damages under severe stress conditions. The synthesis of signal molecules in plants is their most important response to confront environmental stresses. One approach to induce oxidative stress tolerance in plants is to increase intercellular levels of enzyme substrates including AsA. AsA is an essential component of antioxidant defense system and acts as a reducing agent in the removal of $\mathrm{H}_{2} \mathrm{O}_{2}$ (Noctor and Foyer, 1998). However, the protective effects of external applications of AsA are associated with its antioxidant activity in reducing the $\mathrm{H}_{2} \mathrm{O}_{2}$ and malondialdehydes (MDA) concentrations under drought stress conditions (Guo et al., 2005). Some studies have also mentioned the external application of AsA and its positive impact in alleviating the harmful effects of drought stress (Amin et al., 2009; Khalil et al., 2010). Results of some experiments have also shown that the external use of signaling molecules such as SA, has a great potential in improving stress tolerance in plants (Wahid et al., 2007; Zhu, 2002). Any increase in activity of antioxidant enzymes may also be associated with the induction of antioxidant reactions which protect plants against oxidative damages. Hayat et al. (2008) stated that SA caused an increase in CAT activity.

\section{Polyphenol oxidase (PPO)}

ANOVA results also showed that drought stress, foliar application and their interaction significantly affected PPO activity (Table 3). Increasing of intensity of drought stress as a result of irrigation cessation at flowering stage led to increased PPO activity (Fig. 1b). The highest PPO activity (345.29 $\Delta$ OD-mg-protein $\left.\mathrm{min}^{-1}\right)$ was observed in cessation of irrigation at flowering stage and application of salicylic acid $(300 \mu \mathrm{M})$ (Fig. 1b). The lowest PPO activity (30.67 $\Delta$ OD-mg-protein $\mathrm{min}^{-1}$ ) belonged to optimum irrigation and control treatment 
QS1 由S2 圈S3
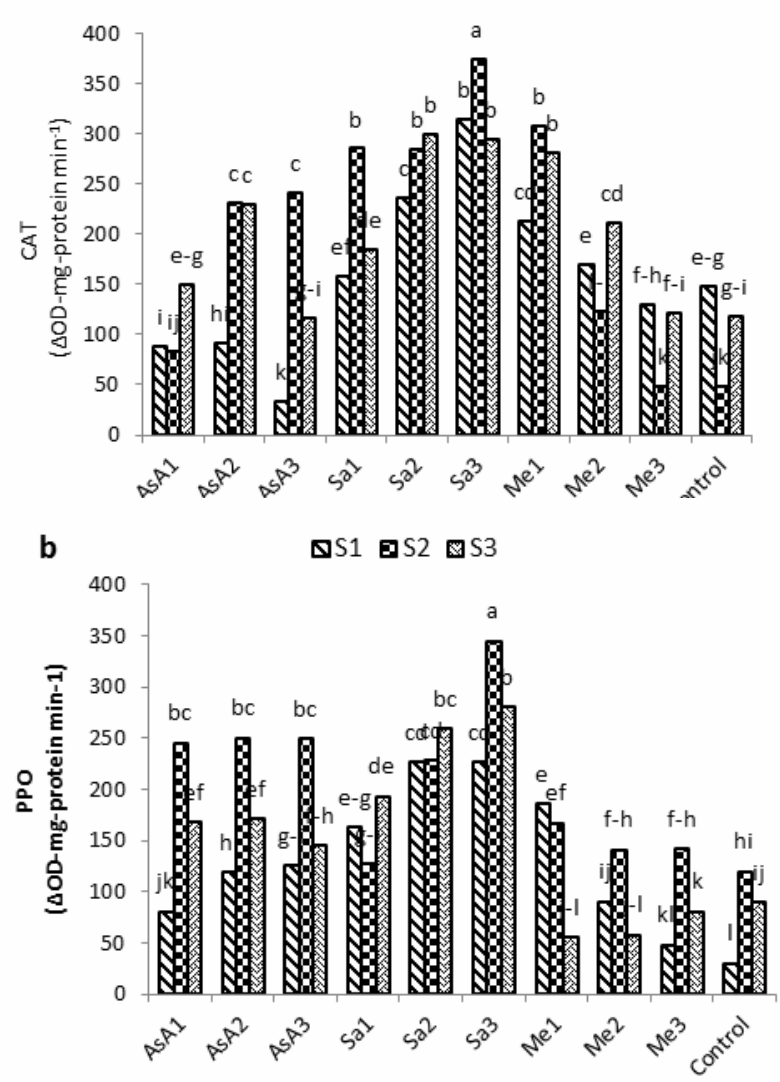

Fig. 1. The interaction effect of irrigation cessation and regulators on CAT (a) and PPO (b)

(foliar spray with distilled water) (Fig. 1b). Increasing methanol concentrations decreased PPO activity under both favorable moisture and cessation of irrigation at the flowering stage conditions. However, the extent of this decrease was higher under favorable moisture conditions compared to the cessation of irrigation at the flowering stage (Fig. 1b). Increasing methanol concentrations together with the cessation of irrigation at the appearance of siliques was followed by an increase in PPO activity, but the extent of this increase was lower compared to the control (foliar application of distilled water) (Fig. 1b). The response of canola plants to the foliar application of AsA under the cessation of irrigation at the flowering stage was similar at all the concentrations and increasing the application rate of AsA did not have a significant effect on PPO activity. Moreover, increasing rates of AsA foliar application under the cessation of irrigation at the appearance of siliques conditions decreased the PPO activity (Fig. 1b). The impact of SA on PPO activity under the cessation of irrigation at both the flowering stage and the appearance of siliques was not the same as that of AsA and increasing rates of SA foliar application increased PPO activity (Fig. 1b). Increasing foliar application rates of methanol decreased PPO activity under both favorable moisture and the cessation of irrigation at the flowering stage conditions (Fig. 1b). Increased antioxidant enzymes activities due to the foliar applications of SA may somehow indicate the alleviation of oxidative stress and the scavenging of ROS by antioxidant enzymes. Preventing the oxidative damages brought to the plant cells during drought stress has been proposed as one of the stress tolerance mechanisms and the extent of this prevention is associated with the increased antioxidant activity. Saruhan $e t$ al. (2012) stated that the external application of SA increased antioxidant enzymes activity in drought-tolerant maize genotypes compared to the susceptible ones.

Peroxidase (PO)

Drought stress, foliar application and their interaction had significant effect on PO activity (Table 3). The highest PO activity (587 $\Delta$ OD-mg-protein $\mathrm{min}^{-1}$ ) was observed in cessation of irrigation at silique stage and foliar application of methanol $(10 \% \mathrm{w} / \mathrm{v})$. The lowest ones (56.07 $\Delta \mathrm{OD}-\mathrm{mg}$ protein $\mathrm{min}^{-1}$ ) belonged to cessation of irrigation at flowering stage and application of AsA (300 mg. $\left.{ }^{-1}\right)$ (Fig. 2a). Increasing application rates of AsA had generally different effects on antioxidant enzymes activities, in such a way that it lead to an increase in CAT and a decrease in PO activity, but did not affect that of PPO under the cessation of irrigation at the flowering stage conditions. Dolatabadian et al. (2008) reported that the application of AsA, significantly increased CAT activity in canola leaves under salinity stress conditions, but had no significant effect on PO activity under favorable (no stress) conditions. They also noted that the application of AsA, however, decreased PO activity in canola leaves under salinity stress conditions. Considering that, increasing foliar application rates of SA under favorable moisture conditions in current study, increased the PO activity; it may be said that it somehow caused damage to the plants, but it was helpful under drought stress conditions resulted by the cessation of irrigation. Stress tolerance in plants may be associated with their ability to scavenge ROS (Saruhan et al., 2012). According to the results obtained in the current experiment, however, the effect of SA in alleviating the negative impacts caused by drought stress was mainly due to an increase in CAT and PPO activities.

\section{Ascorbateperoxidase (APX)}

The maximum APX activity (194.66 $\left.\mu \mathrm{M}-\mathrm{g}-\mathrm{FW} \mathrm{Min}^{-1}\right)$ appointed to cessation of irrigation at flowering stage and foliar application of AsA (300 mg. $\mathrm{I}^{-1}$ ). The minimum APX activity $\left(101 \mu \mathrm{M}\right.$-g-FW $\left.\mathrm{Min}^{-1}\right)$ was observed in optimum irrigation condition and application of distilled water (Fig. 2b). Application of methanol in drought stress conditions led to an increase of APX activity (Fig. 2b). Increased antioxidant enzymes activities under stress conditions may be considered as an indicator of increased production of free radicals. Increasing the foliar application rate of AsA under stress conditions lead to a significant increase in the production of APX, contrary to what happened using the SA, but similar to that of methanol (Fig. 2b). Increasing the foliar application rate of SA under drought stress conditions, however, decreased the production of APX (Table 3). High levels of ascorbate in plants are necessary to maintain the antioxidant system in order to protect them against various environmental stresses (Shigeoka et al., 2002). Amin et al. (2008) stated that the use of AsA lead to an increase in APX production. Results obtained in the current study also showed that APX production was increased as a result of the application of AsA (Fig. 2b).

\section{Soluble sugars}

According to ANOVA results, the effects of stress, foliar application and their interaction were significant on soluble sugars (Table 3). Mean comparisons for the interaction effect of treatments in this experiment showed that soluble sugars content was higher in foliar applications of distilled water 
a

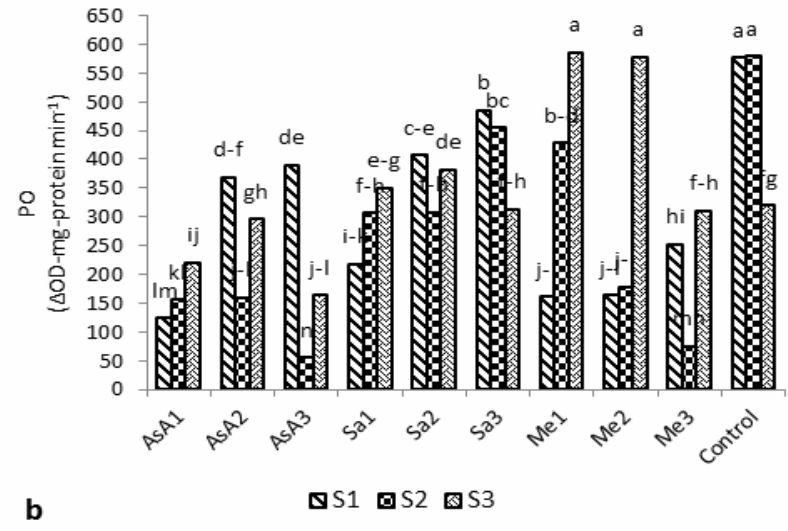

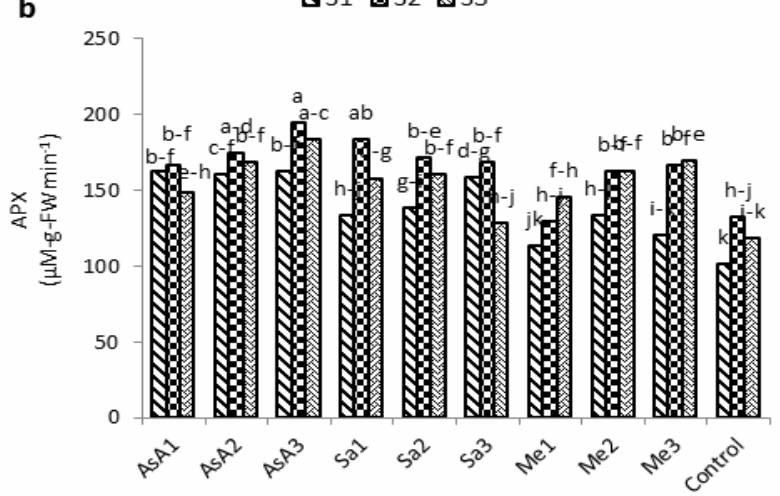

Fig. 2. The interaction effect of irrigation cessation and regulators on $\mathrm{PO}$ (a) and APX (b)

(Control) under all moisture conditions. Foliar application of distilled water led to an increase of soluble sugars by $73 \%, 65 \%$, $75 \%$, respectively, compared to other treatments of foliar application under optimum irrigation, as well as cessation of irrigation at flowering and silique stages. Increased foliar application rates of AsA, SA and methanol under the cessation of irrigation at the flowering stage conditions, however, lead to an increase in the production of soluble sugars (Fig. 3a). Adaptation to drought stress is associated with metabolic regulation which leads to the accumulation of organic salutes such as sugars. Plants facilitate the decrease of osmotic potential and further increase of water absorption through an increase in soluble sugars content. Accumulation of sugars in different parts of the plants has been reported in response to environmental stresses (Prado et al., 2000). It seems that AsA may improve photosynthesis through an increase in chlorophyll content which in turn leads to an increase in the level of assimilates (sugars) produced (Ebrahimian and Bybordi, 2012). Foliar applications of methanol may also be used as an appropriate way to enhance the assimilation of $\mathrm{CO}_{2}$ (Ganjeali, 2012). Bagheri et al. (2014) also reported that soluble sugars content in leaves was increased as a result of foliar application of methanol and the highest contents were obtained in 10 and $20 \%(\mathrm{w} / \mathrm{v})$ treatments of methanol. The positive impact of methanol, however, may be due to its role in reducing the photorespiration and enhancing the net photosynthesis process. Since the accumulation of carbohydrates has been reported during various abiotic stresses, a decrease in sugar content as a result of the elimination of stress seems reasonable (Archbold, 1940).

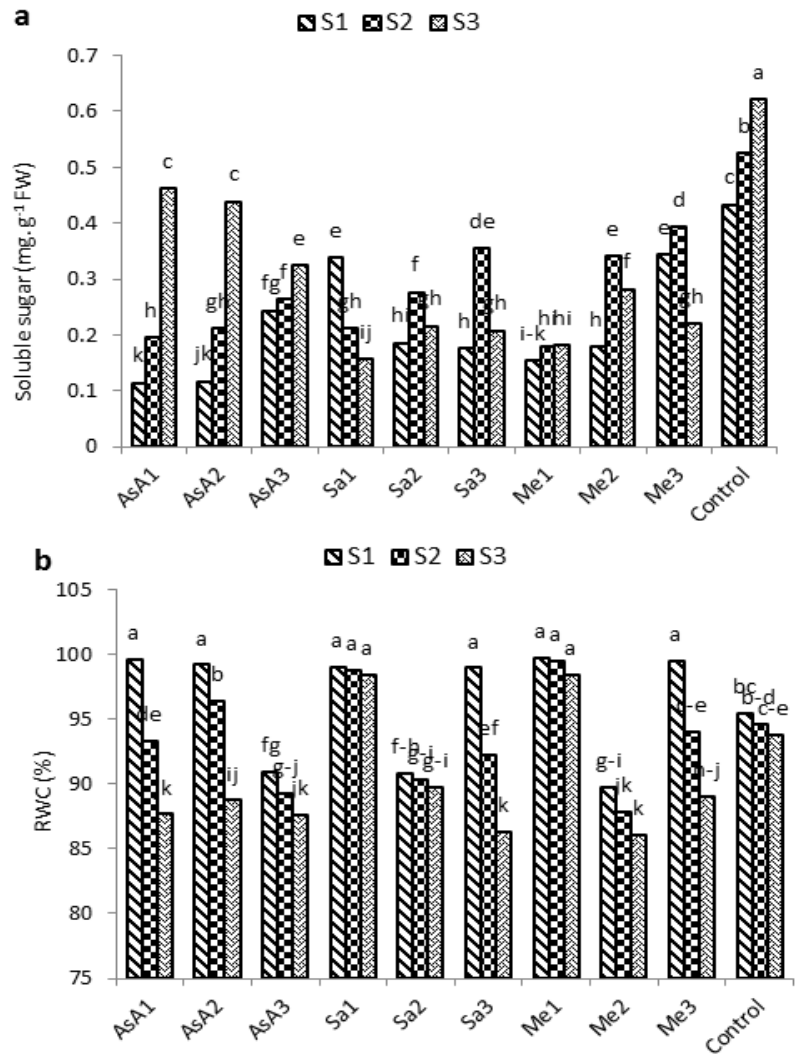

Fig. 3. The interaction effect of irrigation cessation and regulators on soluble sugar (a) and RWC (b)

\section{Relative water content $(R W C)$}

The effects of irrigation deficit, foliar application and their interaction were significant on RWC (Table 3). Means of treatments interaction showed that under favorable moisture conditions and cessation of irrigation at flowering stage, the highest RWC amount belonged to foliar application of 20\% (w/v) treatment of methanol (Fig. 3b). On the other hand, foliar application of methanol $(20 \% \mathrm{w} / \mathrm{v})$ increased RWC by $4.34 \%$ compared to distilled water under optimum irrigation. Decreasing foliar application rates of AsA under both favorable moisture and the cessation of irrigation at the flowering stage conditions, significantly reduced the RWC, but such decrease was not significant under the cessation of irrigation at the appearance of siliques conditions. The foliar application of 300 $\mu \mathrm{M}$ SA had the only significant interaction effect with various moisture conditions studied in this experiment. Considering the higher RWC under the cessation of irrigation at the flowering stage compared to that at the appearance of siliques, it seems that plants have spent more energy to maintain the water potential in their leaves due to the leaves being more active during the flowering stage compared to the time of the appearance of siliques. Foliar applications of organic chemicals have a significant effect on RWC in plants under stress conditions. Since the balance of water in both cells and the whole plant is being sustained through the difference between the absorption of water from the soil and the rate of transpiration, the RWC also decreased due to an increase in transpiration under drought stress conditions, which lead to a decrease in turgor pressure in cells (Tas and Tas, 2007). Raymond and Van Houtte (2012) also reported that an 
increase in foliar application rate of AsA up to $100 \mathrm{mgl}^{-1}$ resulted to an increase in RWC. Considering the results of this experiment, it therefore could be concluded that various foliar application rates of AsA under various soil moisture conditions have different impacts on RWC in plants. SA may also enhance plants tolerance to various environmental stresses (Kolupaev et al., 2011). Foliar application of SA maintains the turgidity in plants by adjusting the opening and closing of stomata. Some researchers also stated that SA enhances the efficiency of photosynthetic apparatus which in turn increases the sap produced in plant leaves and ultimately leads to maintain the RWC in leaves and a better growth of plant $(\mathrm{He}$ et al., 2005; Skhabutdinova et al., 2003). According to the results obtained in the current study, the impact of foliar application of $20 \%(\mathrm{w} / \mathrm{v})$ methanol on RWC under all the moisture conditions was lower than that of the foliar application of $10 \%$ and $30 \%(\mathrm{w} / \mathrm{v})$ methanol and control treatment (foliar application of distilled water). Foliar application of methanol ( $20 \% \mathrm{w} / \mathrm{v})$ enhanced RWC by $9.26 \%$ in comparison with foliar application of AsA (300 mg. $\left.{ }^{-1}\right)$ under the cessation of irrigation at the flowering stage. But under the cessation of irrigation at the silique stage, foliar application of salicylic acid $(100 \mu \mathrm{M})$ had more influence to increase RWC compared to other treatments and this increase was of $12.54 \%$. Foliar applications of methanol under water deficit conditions therefore may alleviate the damages caused by drought stress and also reduce the rate of RWC decrease in plants (Bayat et al., 2012). Makhdum et al. (2002) also reported that foliar application of methanol increased leaf thickness in cotton by $20-50 \%$ and this in turn lead plants to better maintain the RWC in their leaves.

\section{Conclusions}

Plant cells tolerate adverse conditions caused by environmental stresses due to the presence of antioxidant enzymes and the antioxidant system which plays a major role in detoxification of ROS. Taken collectively, the current data reveal a distinct implementation of antioxidant mechanisms in response to drought stress. The external application of signaling molecules such as SA, AsA and methanol, may have a high potential in enhancing the plants tolerance to stress. Based on the results obtained in this experiment, the foliar application of $300 \mathrm{mg} \cdot{ }^{-1}$ AsA in order to enhance the activity of CAT and APX and also the foliar application of $300 \mu \mathrm{mol}$ SA and $10 \%(\mathrm{w} / \mathrm{v})$ methanol in order to enhance CAT, PPO and $\mathrm{PO}$ activity under the cessation of irrigation at the flowering stage, seems appropriate. Moreover, foliar application of methanol $(20 \% \mathrm{w} / \mathrm{v})$ has more role to maintain RWC under cessation of irrigation at the flowering stage, but by decreasing the level of drought stress (cessation of irrigation at the silique stage) foliar application of salicylic acid $(100 \mu \mathrm{M})$ was a suitable treatment to preserve RWC.

\section{References}

Amin A, Rashad ESM, Gharib F (2008). Changes in morphological, physiological and reproductive characters of wheat plants as affected by foliar application with salicylic acid and ascorbic acid. Aust J Basic Appl Sci 2:252-261.
Amin B, Mahleghah G, Mahmood HMR, Hossein M (2009). Evaluation of interaction effect of drought stress with ascorbate and salicylic acid on some of physiological and biochemical parameters in okra (Hibiscus esculentus L.). Res J Biol Sci 4:380-387.

Archbold H (1940). Fructosans in the monocotyledons. A review. New Phytol 39:185-219.

Ashraf M (2009). Biotechnological approach of improving plant salt tolerance using antioxidants as markers. Biotech Adv 27:84-93.

Bagheri HR, Moghadam ARL, Afshari H (2014). The effects of foliar application of methanol on growth and secondary metabolites in lavender. IJBAS 8:150-152.

Bayat V, Paknejad F, Ardakani MR, Vazan S, Azizi J, Mafakheri S (2012). Effect of methanol spraying on physiological characteristics, oil and protein yields of soybean (cv. Williams) under deficit irrigation. Ann Biol Res 3:871-883.

Dolatabadian A, Sanavy S, Chashmi N (2008). The effects of foliar application of ascorbic acid (vitamin C) on antioxidant enzymes activities, lipid peroxidation and proline accumulation of canola (Brassica napus L.) under conditions of salt stress. J Agron Crop Sci 194:206-213.

Downie A, Myazaki S, Bohnert H (2004). Expression profiling of the response of methanol stimulation. Phytochemistry 65:2305-2316.

Ebrahimian E, Bybordi A (2012). Influence of ascorbic acid foliar application on chlorophyll, flavonoids, anthocyanin and soluble sugar contents of sunflower under conditions of water deficit stress.J Food Agric Environ 10:1026-1030.

Ganjeali A (2012). Effects of foliar application of methanol on growth and root characteristics of chickpea (Cicer arietinum L.) under drought stress. EurJ Exp Biol 2:1697-1702.

Gill PK, Sharma AD, Singh P, Bhullar SS (2003). Changes in germination, growth and soluble sugar contents of Sorghum bicolor (L.) Moench seeds under various abiotic stresses. Plant Growth Regul 40:157-162.

Guo Z, Tan H, Zhu Z, Lu S, Zhou B (2005). Effect of intermediates on ascorbic acid and oxalate biosynthesis of rice and in relation to its stress resistance. Plant Physiol Bioch 43:955-962.

Hamada A (2000). Amelioration of drought stress by ascorbic acid, thiamin or aspirin in wheat plants. Indian J Plant Physi 5:358-364.

Hayat S, Hasan SA, Fariduddin Q, Ahmad A (2008). Growth of tomato (Lycopersicon esculentum) in response to salicylic acid under water stress. J Plant Interact 3:297-304.

He Y, Liu Y, Cao W, Huai M, Xu B, Huang B (2005). Effects of salicylic acid on heat tolerance associated with antioxidant metabolism in Kentucky Bluegrass. Crop Science 45(3):988-995.

Idrees M, Khan MMA, Naeem M, Aftab T, Hashmi N, Alam M (2011). Modulation of defence responses by improving photosynthetic activity, antioxidative metabolism, and vincristine and vinblastine accumulation in Catharanthus roseus (L.) G. Don through salicylic acid under water stress. Russ Agr Sci 37:474-482.

Kar M, Mishra D (1976). Catalase, peroxidase and polyphenol oxidase activity during rice leaf senescence. Plant physiol 57:315-319.

Khalil S, Abdel-Aziz N, Abouleil B (2010). Effect of water stress and ascorbic acid on some morphological and biochemical composition 
130

of Ocimum basilicum plant.J Americ Sci 6:33-43.

Kolupaev Y, Yastreb T, Karpets YV, Miroshnichenko N (2011). Influence of salicylic and succinic acids on antioxidant enzymes activity, heat resistance and productivity of Panicum miliaceum L. Journal of Stress Physiology \& Biochemistry 7(2):154-163.

Makhdum M, Malik M, Din S, Ahmad F, Chaudhry F (2002). Physiological response of cotton to methanol foliar application. J Res Sci 13:37-43.

Malik S, Ashraf M (2012). Exogenous application of ascorbic acid stimulates growth and photosynthesis of wheat (Triticum aestivum L.) under drought. Soil Environ 31:72-77.

Mittler R (2002). Oxidative stress, antioxidants and stress tolerance. Trends Plant Sci 7:405-410.

Ndoumou OD, Ndzomo TG, Djocgoue PF (1996). Changes in carbohydrate, amino acid and phenol content in cocoa pods from three clonesafter infection with Phytophthora megakarya Bra. and Grif. Annals of Botany 77(2):153-158.

Noctor G, Foyer CH (1998). Ascorbate and glutathione: keeping active oxygen under control. Annu Rev Plant Biol 49:249-279.

Nonomura AM, Benson AA (1992). The path of carbon in photosynthesis: Methanol and light. Research in Photosynthesis 3:911-914.

Pallardy SG (2010). Physiology of woody plants. 3th Ed. Academic Press. $87 \mathrm{p}$.

Prado FE, Boero C, Gallardo M, Gonzalez JA (2000). Effect of NaCl on germination, growth, and soluble sugar content in Chenopodium quinoa Willd. Seeds. Bot Bull Acad Sin 41:27-34.

Ramberg HA, Bradley JSC, Olson JSC, Nishio JN, Markwell J, Osterman JCO (2002). The role of methanol in promoting plant growth: An update. Rev Plant Biochem Biotechnol 1:113-126.

Raymond F, Houtte V (2012). Effect of water stress, ascorbic acid and spraying time on some morphological and biochemical composition of Ocimum basilicum plant. Int J Agr Envron 2:1-12.

Sakhabutdinova AR, Fatkhutdinova DR (2003). Effect of salicylic acid on the activity of antioxidant enzymes in wheat under condition of salinization. J Applied Biochem Mircrobiol 40:501-505.
Saruhan N, Saglam A, Kadioglu A (2012). Salicylic acid pretreatment induces drought tolerance and delays leaf rolling by inducing antioxidant systems in maize genotypes. Acta Physiol Plant 34:97106.

Shigeoka S, Ishikawa T, Tamoi M, Miyagawa Y, Takeda T, Yabuta Y, Yoshimura K (2002). Regulation and function of ascorbate peroxidase isoenzymes.J Exp Bot 53:1305-1319.

Singh D, Srivastava G, Abdin M (2001). Amelioration of negative effect of water stress in Cassia angustifolia by benzyladenine and/or ascorbic acid. Biol Plantarum 44:141-143.

Strain D, Fletcher J (2003). Plant ascorbic: acid chemistry, function, metabolism, bioavailability and effects of processing. J Sci Food and Agri 80:825-850.

Sudhakar C, Lakshmi A, Giridarakumar S (2001). Changes in the antioxidant enzyme efficacy in two high yielding genotypes of mulberry under $\mathrm{NaCl}$ salinity. Plant Sci 161:613-619.

Tas S, Tas B (2007). Some physiological responses of drought stress in wheat genotypes with different ploidity in Turkiye. World Journal of Agricultural Sciences 3:178-183.

Theodoridou A, Dörnemann D, Kotzabasis K (2002). Lightdependent induction of strongly increased microalgal growth by methanol. Biochim Bioph Acta (BBA)-General Subjects 2:189198.

Ullah F, Bano A, Nosheen A (2012). Effects of plant growth regulators on growth and oil quality of canola (Brassica napus L.) under drought stress. J Bot 44:1873-1880.

Wahid A, Perveen M, Gelani S, Basra S (2007). Pretreatment of seed with $\mathrm{H}_{2} \mathrm{O}_{2}$ improves salt tolerance of wheat seedlings by alleviation of oxidative damage and expression of stress proteins. J Plant Physiol 164:283-294.

Webb RP, Allen RD (1995). Isolation and characterization of a cDNA for spinach cytosolic ascorbate peroxidase. Plant Physiol 108:13-25.

Zheng YJ, Yang YQ, Liang SS, YI XF (2008). Effect of methanol on photosynthesis and chlorophyll fluorescence of flag leaves of winter wheat. Agricultural Sciences in China 7:432-437.

Zhu JK (2002). Salt and drought stress signal transduction in plants. Ann Rev Plant Biol 53:247-273. 